POLIIICAL ECONOMY RESEARCH INSTIIUIE

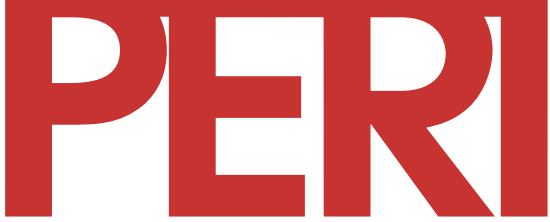

University of Massachusetts Amherst

\title{
Social Attitudes, Labor Law, and Union Organizing: Toward A New Economics of Union Density
}

Thomas I. Palley and Robert M. LaJeunesse 2005

10th floor Thompson Hall University of Massachusetts Amherst, MA, 01003-7510 Telephone: (413) 545-6355 Facsimile: (413) 545-2921 Email:peri@econs.umass.edu Website:

http://www.umass.edu/peri/

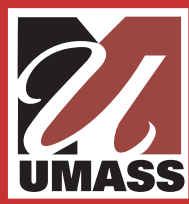




\title{
Social Attitudes, Labor Law, and Union Organizing: Toward A New Economics of Union Density
}

\begin{abstract}
Much has been written about union wage bargaining. Much less has been written about union density, which has been viewed as simply the employment outcome under the wage bargain. This paper presents a new dynamic model of union density that exhibits multiple equilibria and path-dependency. The model builds upon Freeman (1998) who identified the importance of union spending on organizing and business spending on opposing unions. It emphasizes the demand for union representation which depends on wage bargaining outcomes, the state of labor law, and socio-economic factors impacting public attitudes to unions. The model is used to provide a narrative account of the historical evolution of union density in the U.S. and to identify factors important for its future evolution.
\end{abstract}

Keywords: Union density, labor law, union organizing, employer opposition.

JEL ref.: J5

\author{
Thomas I. Palley \\ Chief Economist \\ U.S. - China Economic \& Security Review Commission \\ Washington, DC 20001 \\ tpalley@uscc.gov
}

And

Robert M. LaJeunesse

University of Newcastle

Newcastle, Australia

Department of Economics

Robert.lajeunesse@newcastle.edu.au

This version January 23, 2005 


\section{Introduction}

Much has been written about the theory of union wage bargaining, but relatively less research has been devoted to the density of union membership. Union density has tended to be viewed as simply the product of the employment outcome under the wage bargain. Whereas such an approach makes sense in times when the underlying state of union density is given, it makes much less sense when it comes to explaining the massive fluctuations that have occurred in the historical evolution of union density within the U.S. economy over the last hundred years.

Our approach seeks to remedy this weakness in the literature on the economics of unions. It presents a dynamic model of union density that exhibits the possibility of multiple equilibria. The model builds upon Freeman (1998) who identified the importance of union spending on organizing and business spending on union busting. However, it extends the analysis to include wage bargaining effects, as well as socio-economic factors such as the state of labor law and public attitudes about unions. The model is used to provide a narrative account of the historical evolution of union density in the U.S. economy. The paper closes by identifying a new microeconomic research agenda that grows out of an explicit focus on union density.

\section{Shifting the focus: from union bargaining to union density}

Economists have long had an interest in the economic effects of unions. However, a distinct feature of this interest has been a tendency to focus on firm-level impacts. This is typified by the monopoly union model in which the union is taken as an institutional given, and the union acts as a monopoly supplier of labor to the firm. Given this, wages and employment are determined by the union's preferences over wages and employment given the firm's labor demand curve. 
There are many variants of this firm level approach to unions. Nash bargaining models (McDonald and Solow, 1981) have the firm and union jointly solving a program that maximizes the product of their respective objective functions subject to each realizing a minimum acceptable outcome. This co-operative bargaining model results in a Pareto efficient outcome (which is sensible from a classical maximization perspective), but enforcement of the bargain also requires counter-factually that unions have control over the level of employment. Noncooperative bargaining theory (Shaked and Sutton, 1981; Skillman, 1991; Skillman and Ryder, 1993) provides another approach to union wage determination, with the outcome depending on bargaining costs to the firm and union, the magnitude of "outside" payoffs to the firm and union, and the rules governing the bargaining process. ${ }^{1}$ Though bargaining models break with the monopoly union model's unrealistic claim that unions unilaterally set wages subject only to the constraint of firms' labor demand schedules, they remain focused on firm level analysis and take the existence of the union as given.

Two sector union - non-union models broaden the scope of analysis and make way for a more realistic treatment of union density. McDonald and Solow (1985) present a model in which union wages are set by Nash bargaining and non-union wages are set competitively. Given this process of wage setting, union employment and density fluctuates with shifts in the union sector labor demand curve. Palley (1988) presents a two-sector model with a monopoly union. The innovation in that paper is that union preferences over wages and employment are endogenous and respond to the level of unemployment amongst union members. In this model, union membership includes both employed and unemployed members, and membership can expand in response to positive labor demand shocks in the unionized sector. Unemployed union members 
may also drift out of the union sector in response to positive wage and employment shocks in the non-unionized sector, or in response to large negative wage and employment shocks in the unionized sector that lower union compensation premiums.

Such two sector models begin the process of explaining union density, but their approach is narrow. Thus, the union is taken as a given and density depends on the wage bargain and the state of sectoral labor demand. However, there is no mention of union organizing efforts or business opposition efforts. Nor is there any mention of worker attitudes toward unions. In effect, the two-sector union - non-union model can be thought of as providing a picture of union density at a historical moment in time conditional on a given state of unions as an institutional presence.

Although the two-sector model is an improvement on the single firm union model, such an approach is inadequate to the task of explaining the historical evolution of union density within the U.S. economy. Instead, accounting for unions as an institutional force requires a more fundamental analysis that emphasizes the social setting that girds the presence of unions. Such an analysis can be conceptualized in terms of the demand for and supply of union services, and the conditions governing demand and supply vary in accordance with historical circumstance. Hogler, Shulman and Weiler, (2003) have incorporated some of the social influences affecting union density across states, such as employer opposition, right to work laws and an aversion to collective action as measured by falling social capital. Although helpful in assessing the motivations of workers to unionize at a point in time, their cross-sectional approach does not fully capture the dynamic evolution of union density over time. Nevertheless, their analysis of union density across states indicates that preferences for unions matter, as does the ability of 
unions to provide representation. Both features impact the dynamic evolution of union density.

\section{A dynamic multiple-equilibria model of union density}

The history of union density within the U.S. economy is shown in Figure 1. Density was 6.78\% in 1900 and rose gradually to $13.24 \%$ in 1936 . There then occurred a remarkable spurt with density rising to $34.23 \%$ in 1945 . For the next twenty five years density declined slowly to $23.36 \%$ in 1979 , but thereafter the decline accelerated as union density fell to just $14.03 \%$ in 1995 - approximately the same level as it was in the 1930s.

$<$ Figure 1 near here $>$

How are we to account for this massive variation? Freeman (1998) presents a supply and demand model of union density that emphasizes union spending on organizing and business spending opposing organizing efforts. The model is given by

(1) $\mathrm{U}_{\mathrm{t}}=[1-\mathrm{r}] \mathrm{U}_{\mathrm{t}-1}+\mathrm{NEW}_{\mathrm{t}} \quad 0<\mathrm{r}<1$

(2) $\mathrm{NEW}_{\mathrm{t}}=\mathrm{f}\left(\mathrm{ORG}_{\mathrm{t}}, \mathrm{OPP}_{\mathrm{t}}\right) \quad \mathrm{f}_{1}>0$ for $\mathrm{U}_{\mathrm{t}-1}<\mathrm{U}^{*}$ and $\mathrm{f}_{1}<0$ for $\mathrm{U}_{\mathrm{t}-1}>\mathrm{U}^{*}, \mathrm{f}_{2}<0$

(3) $\mathrm{ORG}_{\mathrm{t}}=\mathrm{g}\left(\mathrm{U}_{\mathrm{t}-1}\right) \quad \mathrm{g}_{1}>0$ for $\mathrm{U}_{\mathrm{t}-1}<\mathrm{U}^{*}$ and $\mathrm{g}_{1}<0$ for $\mathrm{U}_{\mathrm{t}-1}>\mathrm{U}^{*}$

(4) $\mathrm{OPP}_{\mathrm{t}}=\mathrm{h}\left(\mathrm{U}_{\mathrm{t}-1}\right) \quad \mathrm{h}_{1}>0$

Where $\mathrm{U}=$ union density

$\mathrm{r}=$ attrition of unionized firms

$\mathrm{NEW}=$ new members

ORG = union spending on organizing

OPP = business spending on opposing organizing

Equation (1) is the equation of motion determining the dynamic evolution of union density as a function of union attrition and new membership. Equation (2) determines new membership as a function of union organizing expenditures and business opposition to organizing expenditures. Equation (3) determines union spending as a function of union density. This function is concave and peaks at $\mathrm{U}^{*}$, reflecting diminishing returns to union spending on organizing. Finally, 
equation (4) determines business expenditures opposing organizing as a strictly negative function of union density.

The microeconomics of the system are embedded in equations (3) and (4). The logic of equation (3) is as follows. Initially, net marginal benefits to organizing are positive. At low levels of density, increases in density promote significantly higher wages from which union dues are payable. Moreover, unions can pick those workers that can be organized at least cost. However, as density increases, the wage gains from additional density decline and the cost of organizing marginal (more difficult to reach) workers rises, so that spending on organizing falls off. The logic to equation (4) is that as union density increases, unions become more powerful and more capable of disciplining firms. ${ }^{2}$ It therefore becomes more costly to oppose unions, and business opposition spending declines.

Figure 2 shows the determination of equilibrium union density. ${ }^{3}$ The ray from the origin determines the decline in density arising from normal attrition of union jobs. The concave function determines the flow addition to density from new organizing. Initially it is increasing as the effects of spending on organizing outweigh the effects of spending against organizing. However, this function becomes negatively sloped as unions eventually cut back on spending owing to accelerating diminishing returns to the organizing dollar as union density increases. There are two equilibria. The lower equilibrium (marked A) is unstable, while the upper equilibrium (marked B) is stable. According to this model, increases in density result from

2 We propose below that the achievement of high union density leads to an increased cost of employer opposition and also creates a path-dependent (or hysteresis) effect to union organizing. Path dependency arises because as union density increases, workers become more aware of the benefits of unionization, making it even more costly for firms to oppose unions.

3 The solution shown in figure 2 is different from that shown in Freeman (1998) who shows unions and business as spending equal amounts on organizing and opposition in equilibrium. In fact, they spend different amounts, but the marginal impact of organizing and opposition spending on new membership is identical. 
upward shifts of the new membership function, while decreases result from downward shifts.

$<$ Figure 2 near here $>$

Freeman's (1998) focus on the endogeneity of union density, the significance of union spending on organizing, and the significance of business spending on opposing unions are welcome innovations. Yet, at the same time the model appears incomplete. There is no reference to the demand for union membership (tastes), or the institutional and legal context in which organizing takes place. Nor is there any mention of the union wage premium, a strictly economic factor that is widely believed to be important in explaining why workers join unions, and why business opposes unions.

From a historical perspective, there is little in the Freeman model that accounts for the astounding increase in union density between 1936 and 1944. Similarly, there seems little to explain the accelerated rate of decline in the 1970s and 1980s. Though capturing the conflict between unions and firms, the model does not provide an account of the factors impacting the new membership function. These factors may include conventional economic factors such as the union wage premium, as well as less conventional sociological and institutional factors such as public attitudes toward unions, changes in labor law and the effects of path dependency.

Reflection upon the underlying factors influencing union density suggests reformulating the model to capture the "stock" demand for density, as well as focusing on the "flow" increment to density. This is done in the following model, which can be thought of as a dynamic model of the demand and supply for union density. The equations of the model are:

(5) $\mathrm{p}=\mathrm{W}_{\mathrm{UNION}} / \mathrm{W}_{\mathrm{MKT}}$

(6) $\mathrm{W}_{\mathrm{UNION}}=\mathrm{W}\left(\mathrm{U}_{\mathrm{t}-1, \ldots \ldots .)}\right.$ - DUES $>\mathrm{W}_{\text {MKT }} \quad \mathrm{W}_{1}>0$

(7) $\mathrm{W}_{\mathrm{MKT}}=\mathrm{V}\left(\mathrm{U}_{\mathrm{t}-1, \ldots . .)} \quad \mathrm{V}_{1}>0\right.$ 
(8) $\mathrm{ORG}=\mathrm{g}\left(\mathrm{U}_{\mathrm{t}-1}, \mathrm{DUES}\right.$, LAW $)$

0

(9) $\mathrm{OPP}=\mathrm{h}\left(\mathrm{W}\left(\mathrm{U}_{\mathrm{t}-1}, \ldots \ldots ..\right) / \mathrm{W}_{\mathrm{MKT}}, \mathrm{U}_{\mathrm{t}-1}, \mathrm{LAW}\right)$

(10) $\mathrm{D}=\mathrm{D}(\mathrm{p}, \mathrm{ORG}, \mathrm{OPP}, \mathrm{ATT}, \mathrm{TREAT}, .$.

(11) $\mathrm{ATT}=\mathrm{U}\left(\mathrm{U}_{\mathrm{t}-1}\right)$

(12) $\mathrm{TREAT}=\mathrm{t}\left(\mathrm{U}_{\mathrm{t}-1}, \mathrm{LAW}\right)$

(13) $\mathrm{U}_{\mathrm{t}-1}=\mathrm{Q}\left(\mathrm{D}-\mathrm{U}_{\mathrm{t}-1}\right)$

$$
\mathrm{g}_{1}>0 \text { for } \mathrm{U}_{\mathrm{t}-1}<\mathrm{U}^{*} \text { and } \mathrm{g}_{1}<0 \text { for } \mathrm{U}_{\mathrm{t}-1}>\mathrm{U}^{*}, \mathrm{~g}_{2}>
$$

$$
\mathrm{h}_{1}>0, \mathrm{~h}_{2}<0, \mathrm{~h}_{3}<0
$$

$\mathrm{D}_{1}>0, \mathrm{D}_{2}>0, \mathrm{D}_{3}<0, \mathrm{D}_{4}>0, \mathrm{D}_{5}>0, \mathrm{D}_{6}<0$

$$
\begin{aligned}
& \mathrm{T}_{1}>0, \mathrm{~T}_{2}>0 \\
& \mathrm{Q}_{1}>0
\end{aligned}
$$

Where:

$\mathrm{U}=$ union density

$\mathrm{p}=$ union wage premium ratio

$\mathrm{W}_{\text {UNION }}=$ union wage after payment of dues

$\mathrm{W}_{\mathrm{MKT}}=$ market wage

DUES = union dues per worker

ORG = union spending on organizing

OPP = business spending on opposing unions

LAW = index of favorableness of labor law towards unions and organizing

$\mathrm{D}=$ worker demand for unions (\% of workers)

ATT = index of favorableness of worker attitudes towards unions

TREAT $=$ worker treatment by employers

The exogenous variables are DUES and LAW.

Equation (5) defines the union wage premium. Equation (6) determines the union wage net of dues payments, and it is assumed to be greater than the market wage. The union wage is a positive function of union density. ${ }^{4}$ The market wage is also a positive function of union density, as indicated in equation (7). ${ }^{5}$ This positive relation reflects the fact that non-union firms pay a premium to discourage formation of unions - and it is shown below that this practice reduces equilibrium union density. Finally, both the union and the market wage include payroll taxes,

4 Equation (6) can be identified as a union "wage curve”. This is the union analog of the unemployment wage curve identified by Blanchflower and Oswald (1994). The latter has wages being a negative function of the unemployment rate.

5 This practice is clearly evident in the U.S. auto industry where firms such as Honda, Toyota, BMW, and Mercedes 
health benefits, and pension benefits. These factors impact both the benefit to workers and the cost to employers of having unions.

Equation (8) is the organizing function, which is an augmented version of equation (4) in the Freeman (1998) model. The ORG variable measures the resources devoted to organizing efforts by unions. As union density (U) increases, unions initially spend more. However, beyond a threshold density, organizing spending declines for two reasons. First, unions come to exercise significant control over the market so that there is little additional bargaining strength to be gained from additional membership. Second, those areas that remain non-unionized tend to be the most hostile and least tractable to organizing, discouraging unions from spending resources on them. Finally, the level of organizing expenditure is positively influenced by the level of dues and the favorableness of labor law. Dues provide unions with the resources to spend, while the favorableness of labor law positively impacts the membership yield from devoting additional dollars to organizing spending.

Equation (9) is an augmented version of Freeman's business opposition expenditure function, with the OPP variable measuring business spending on opposing unions. ${ }^{6}$ Spending against unions is positively impacted by the union wage premium, with business having a clear and increasing incentive to oppose unions as this premium rises. Second, business opposition spending is negatively related to union density. The competitive disadvantage the firm may face related to paying union wages is diminished at high union density levels, as there are fewer opportunities to compete on the basis of payroll costs when the majority of firms in the industry are unionized. Finally, opposition spending is negatively influenced by the favorableness of

all pay above local market wages as a means of blunting the union organizing efforts of the UAW.

6 The OPP variable refers to employer opposition in its broadest sense. This includes opposition to union elections, and also includes efforts to bust unions by changing the location of employment. 
labor laws towards unions since the impact of spending diminishes as labor law becomes more favorable.

Equation (10) is the current demand for union membership, which determines the number of workers who actually join unions. ${ }^{7}$ Worker demand for unions depends positively on the union wage premium, union organizing spending, and worker attitudes toward unions and prounion labor laws. It depends negatively on business opposition spending. In their review of the literature on measures of public opinion of unions, Hogler, Shulman and Weiler (2003) claim that "culture" is an important dimension of workers propensity for unionization and should be taken into account in assessing membership trends. Attitudes can be thought of capturing this effect. The demand for union representation also depends negatively on firms' treatment of workers.

Equation (11) determines the quality of worker treatment. This depends positively on the extent of union density (a union threat effect), and positively on the extent of labor law protections for workers (i.e. a "just cause" employment contract). Equation (12) determines worker attitudes towards unions. The model proposes characterizing attitudes as subject to hysteresis, a representation that has hitherto been overlooked in models of union organizing. Hysteresis, in the general sense, refers to a system in which the reaction of the system to changes is dependent upon its past reactions. In other labor market applications, for example, hysteresis has been used to show that longer durations of unemployment will lead to higher unemployment levels because unemployment destroys human capital. In the current application, attitudes about

7 It is worth distinguishing between "worker demand" for union representation which is expressed by actually joining unions, and "worker desires" for union representation which reflect wants. Surveys show that worker desire for unions greatly exceeds demand. However, in contemporary U.S. labor markets workers are unable to turn their wants for union representation into union membership due in large part to the weak state of labor law regarding protection against dismissal. 
unions - which affect current demand for unions - depend on the past level of union density. The logic is that as fewer workers are engaged in union activities, less familiarity and goodwill is transferred to children, relatives, and younger workers. In other words, a young worker is likely to be more cognizant and favorably disposed to unions if a parent was a union member. ${ }^{8}$ Thus, low or high union density has reinforcing effects that become a self-fulfilling prophecy.

Lastly, equation (13) is the equation of motion (in continuous time) governing union density, and density grows when demand for density exceeds actual density.

Substituting equations (6) and (7) into equation (5) yields an expression for the union wage premium as a function of union density

(5') $\mathrm{p}=\left[\mathrm{W}\left(\mathrm{U}_{\mathrm{t}-1}, \ldots \ldots.\right)-\mathrm{DUES}\right] / \mathrm{V}\left(\mathrm{U}_{\mathrm{t}-1}, \ldots ..\right)$

This function is illustrated in Figure 3, which shows the wage premium to be a non-linear quasiconcave function of union density. The logic is that union strength is relatively weak at low levels of density so that the premium is relatively small. As density grows, union bargaining strength increases dramatically and the union wage premium also increases rapidly. However, increased density beyond a certain level brings declining increments to bargaining strength, and non-union firms may also increase the market wage to discourage unionization. Consequently, the union wage premium function tapers off. ${ }^{9}$

$<$ Figure 3 near here $>$

Figure 4 shows the graphical analogue of the full model. The demand for union density function has the same non-linear S-shape as the wage premium function because the latter is nested within it. The reduced form demand schedule is given by

8 In a sense, there is a form of endogeneity of preferences toward unions.

9 The union wage function can be thought of as embodying conventional microeconomic bargaining concerns found in the theoretical literature on union bargaining. 
(10)

$$
\begin{aligned}
D=D\left(\left[W\left(U_{t-1}, \ldots . .\right)\right.\right. & -\operatorname{DUES}] / V\left(U_{t-1}, \ldots . .\right), g\left(U_{t-1}, \text { DUES, } L A W\right) \\
& \left.h\left(W\left(U_{t-1}, \ldots . .\right) / V\left(U_{t-1}, \ldots . .\right), U_{t-1}, L A W\right), \operatorname{ATT}\left(U_{t-1}\right), t\left(U_{t-1}, L A W\right), \ldots .\right)
\end{aligned}
$$

There are three possible equilibria. The outer two equilibria (marked A and C) are stable, while the inner equilibrium (marked B) is unstable. Equilibrium density increases when the demand function shifts up: it decreases when the demand function shifts down.

$<$ Figure 4 near here $>$

\section{Explaining the evolution of union density in the U.S. economy}

The above model can be used to provide a narrative account of the historical evolution of union density within the U.S. economy. Figure 1 suggests that four distinct periods can be identified: 1880 - 1935, 1936 - 1958, 1959 - 1971, and 1972 - present.

Period I: 1880 - 1935.

The late $19^{\text {th }}$ century saw the emergence of the American labor movement as a means to counterbalance the increased bargaining power of the capitalist in the wake of a massive consolidation of industry. The thrust of industrial consolidation in the late 1800s originated from technological development that rewarded large fixed costs and the capture of greater market share (Heilbroner and Singer, 1996). Technological advance over this period was prodigious, and can be categorized into four clusters: 1) electricity, light and consumer appliances; 2) combustion engines, transportation and industrial mechanization; 3) chemical engineering (petrochemicals, pharmaceuticals, and metallurgy); 4) communications and entertainment (telephone, radio, movies, etc.). Implementation of the new technology was costly and required large profits. In order to pay down the large fixed costs of industrial technology, firms were increasingly faced with the choice of either engaging in cutthroat competition for more market share or price collusion through pools, trusts, and eventually, mergers. The consolidation that 
followed this rapid technological discovery led Alfred Chandler (1977) to comment that, "the visible hand of management replaced the invisible hand of the market.” With fewer employers to choose from, and with final product prices taken out of competition, workers saw their real wages and working conditions deteriorate tremendously.

Dramatic demographic changes to the labor force also created a drag on wages and working conditions. The Immigration Act of 1864 legalized the entry of cheap labor from Europe and China, and by 1870 a third of all manufacturing workers in the US were foreignborn. Many immigrants from southern and eastern Europe were concentrated in the "dirty" industries -- by 1907, over four-fifths of the workers in Carnegie’s Allegheny plants were eastern Europeans (Heilbroner and Singer, 1999). This cosmopolitan workforce was a feature of most industrial towns in America. By 1880 immigrants comprised 90 percent of the population in New York, Cleveland, Detroit, Milwaukee and Chicago. Immigrants typically worked for low wages under abject conditions and were difficult to unionize. Unions were initially reluctant to welcome foreigners into their union halls. Moreover, cultural and language barriers made it difficult for those organizers that eventually tried to embrace immigrants workers. Immigrants were much more diffident towards their employer than domestic workers as they were not familiar with their rights to organize and were more accepting of paternalistic employment relationships (Heilbroner and Singer, 1999). Moreover, opportunistic employers often played one group of ethnic immigrants against another in an attempt to lower wages.

In the midst of this change, a small portion of the workforce embraced the practice of collective bargaining as a way to take wages out of competition and to ameliorate the dangerous working conditions of the Industrial Revolution. Union density increased from 1.61\% in 1880 to $11.87 \%$ in 1904 . This period can be viewed as one of convergence toward the low-density 
equilibrium identified as point $\mathrm{A}$ in Figure 4 above. In the next twenty-one years union density remained roughly unchanged, being $12.79 \%$ in 1935 . However, there were fluctuations around the equilibrium point reflecting changes in business opposition efforts and changes in the buoyancy of labor markets. The low mark was $8.94 \%$ in 1909; the high mark was $17.40 \%$ in 1921, with this spurt being driven by America’s entry into World War I.

The relatively low level of union density during this period begs the question of "why more workers were not unionizing in the face of such low wages, long hours, and unsafe working conditions?” The state of labor law goes a long way in explaining the barriers to unionization, but the culture and mentality of the time is also a factor. Prior to the New Deal legislation of the 1930s, there were few federal laws protecting workers' right to organize. ${ }^{10}$ Moreover, cultural attitudes militated against the growth of unions. Dramatic increases in labor productivity, output, profitability and scientific discovery, may also have encouraged hopes of upward economic mobility that generated greater short-term acceptance of wider inequality. Even the most impoverished workers were optimistic that it was just a matter of time before their "ship would come in.” This expectation of leaping from the working class to the leisure class, led Beard $(1933,395)$ to comment that, "there was a baton [and top hat] in every toolkit.” However, such optimism was dashed by the extreme experience of the Great Depression, which radicalized working class demands for economic stability.

Period II: 1936 - 1958.

The Great Depression changed worker beliefs about the nature of market economies and made workers in the post-depression era much more receptive to the need for collective bargaining. Beginning in the mid 1930s, there ensued a period of rapid growth in union density 
which jumped from $13.24 \%$ in 1936 to $34.23 \%$ in 1945. In the thirteen years thereafter, union density remained close to the top end of this range, being $32.01 \%$ in 1958 . This sudden spurt was the result of a massive shift in the demand for union density, driven by a deep-seated suspicion of the free market's capacity to provide adequate levels of employment and compensation. As shown in Figure 5, this shift freed the economy from the pull of the low-density equilibrium and made the high-density equilibrium the unique equilibrium. Absent the epochal events surrounding the Great Depression, it is possible that union density would have remained trapped in the low-density equilibrium.

$<$ Figure 5 near here $>$

There are a number of factors that account for the shift. First, since unions were better able to protect their members' wages, the union wage premium rose in the Depression because market wages fell. Second, there was a significant improvement in public attitudes towards unions, which were widely viewed as protecting working people against the abuses and inequalities of market economics. This shift is clearly visible in the art and literature of the period. “Labor” became a "cause” amongst artists, public intellectuals, and academics, as exemplified in Clifford Odets' 1935 play “Waiting for Lefty.” Third, there was a significant change in labor law - itself the result of changed public attitudes. Beginning with the New Deal legislative efforts, the Federal government took the lead in tilting the legal scales in favor of the working class. The monumental changes in US labor law that followed fostered union security clauses, promoting dramatic growth of union density during this period. Many of Roosevelt's legislative acts -such as the National Industrial Recovery Act (NIRA)- extended protections to workers who were seeking more power in the employment bargaining process. Section 7(a) of 
the NIRA gave employees the "right to organize and bargain collectively through representatives of their own choosing." Given that there was a rancorous debate at the time over whether company unions (versus trade unions) should be allowed to enter into closed shop arrangements, the NIRA also established the National Labor Board to determine whether or not those employee associations were in fact "freely chosen."

Robert Wagner's opposition to company unions was that they failed to give workers adequate power. This objection coincided with the chief macroeconomic objective of the New Deal legislation - the establishment of sufficient bargaining power to effectively redistribute economic resources (Taussig, 1929). Wagner’s legislation offered workers the right to choose exclusive representation with an independent (non-employer) union and to request compulsory membership of all employees. The Wagner (or National Labor Relations) Act, passed in July 1935, established the National Labor Relations Board (NLRB) to enforce workers’ rights to form unions and bargain collectively. Its constitutionality was upheld by the Supreme Court in NLRB v. Jones and Laughlin (April 1937). The promotion of this “closed-shop” employment practice and the consequent growth in unionization serves as a powerful indicator of the importance of the legal climate for union density.

Although, the favorable organizing conditions brought on by the Wagner Act were curtailed somewhat with the passage of the Taft-Hartley Act of 1947, union density continued increasing into the mid-1950s. Having reached a critical union density level, it became easier for unions to organize new members, since young workers were readily familiar with the objectives and accomplishments of the labor movement. Meanwhile, high union density levels raised the stakes for employers opposing collective bargaining arrangements.

precedence for the Wagner Act, was not signed into law until 1933. 
Period III: 1959 - 1979.

The period 1959 - 1979 is marked by two important changes. First, there is the beginning of decline in overall union density. Second, it is marked by a surge in public sector union density that has ultimately changed the composition of union density. Whereas private sector union density was the engine of growth for union density in the previous two periods, throughout the 1960s and 1970s union density in the private sector began to wane. In 1970, private sector union density stood at 29.1 percent, but it would fall to roughly half that size within 14 years (15.5 in 1984). Conversely unionization in the public sector jumped from 10.5 percent in 1959 to 36.4 percent in 1979.

The decline of union density in the private sector coincides with a weakening in public support for unions that became manifest in the late 1970s. Since public opinion is particularly important in organizing new (or low density) sectors of the economy, it stands to reason that diminished public support for unions would be felt the hardest in private sector. Public approval of unions, at least to some degree, affects the success of both union organizing and strikes. Medoff (1984) has shown that there is a strong negative correlation between workers' voting for representative in NLRB elections and their image of unions. He also suggests that the voting patterns of local, state and federal politicians are responsive to public opinion regarding unions. Finally, Medoff (1984) contends that companies are given more leeway to commit unfair labor practices when there is little sympathy for unions. The effects of the waning support for unions in the 1970s and 1980s can be seen in Figure 6, which shows growing union disapproval ratings corresponding to the low-points of the percent of union elections won by labor, as well as a slight reversal in recent years. 
$<$ Figure 6 near here $>$

Much of the jump in public sector unionization can be explained by policy changes undertaken in the 1960s. In 1961, President Kennedy’s Labor-Management Relations Commission found that there was no overall personnel pattern from one agency to the next and that various agencies had adopted counterproductive arrangements when dealing with unions. John F. Kennedy then issued Executive Order 10988 in an effort to standardize the manner in which Executive branch agencies interacted with unions. The most unique feature of Executive Order 10998 was its establishment of tri-level membership recognition. If an employee association or labor union represented a majority of the employees in an agency (with at least 60 percent of the employees voting), it was granted “exclusive recognition.” If it had between 10 and 50 percent, the union received "formal recognition." An association of less than 10 percent was granted “informal recognition.” This contrasts sharply with almost all other industrial relations laws in the United States where only exclusive recognition is allowed. Consequently, competing minority unions could and did exist in many federal agencies and union membership in the public sector grew rapidly in the years following. By 1970 the federal work force was 48 percent unionized, revealing the importance of legal environment for union density.

In 1969, President Nixon took steps to make the labor-management practices in the public sector more compatible with the private sector. Nixon issued his own Executive Order (E.O. 11491), which contained a stronger duty to "meet and confer in good faith,” and also contained a "killer" management rights clause that restricted the scope of bargaining considerably. It also ended the three-level recognition arrangement and replaced it with exclusive recognition only. The result was that the minority unions disappeared but larger unions 
continued to grow. By 1978, about 60 percent of federal workers were unionizedapproximately the same union density as today.

In addition to federal organizing regulations, each of the 50 states has some sort of collective bargaining law governing state employees. In all but 10 states the right of public sector employees to strike is greatly restricted. These legal complexities and outright strike restrictions raise additional issues for understanding public sector union density. However, the model we propose is still applicable, though it may require the addition of political variables.

Overall, the period 1959 - 1979 witnessed a slow steady erosion of total union density from $31.01 \%$ to $23.36 \%$, which would have been much more drastic absent the surge in public sector unionization. This period can be identified with a slow steady downward drift of the density demand function, as shown in figure 7. Although the economy remained within the field of attraction of the high equilibrium point, the lower level of absolute union density (along the horizontal axis) lowered the cost of employer opposition activities. This created an incentive for employers to raise their opposition. Moreover, as density fell, path-dependency effects began to tilt in favor of employers.

$<$ Figure 7 near here $>$

The reasons for this shift are multiple. One element was a gradual weakening of public support for unions, which came to be more identified with the narrower interests of their members. A lack of public support for unions diminishes the returns to organizing efforts, while reducing the costs of opposition for employers. The shift in attitude was likely fostered by the Cold War, which contributed to a mentality that was inimical to collective action as a means of dealing with economic problems. Indeed, the shift to narrow industrial unionism away from 
broader social unionism may itself have been prompted by the Cold War as unions sought to distance themselves from possible charges of Communism. Finally, the prosperity of the 1950s relative to the Depression era may have contributed to a belief that Keynesianism had permanently solved earlier economic difficulties. Keynesian fiscal policy, rather than unions, therefore came to be seen as the principal solution to the inadequacy and instability of aggregate demand that often afflicts market economies. ${ }^{11}$

Coupled with deteriorating public opinions about unions, changes in labor law began to swing strongly in favor of business. A critical piece of the Taft-Hartley (1947) legislation was section 14b, which allowed states to pass so-called "right to work" laws. Right to work laws reduce union security by prohibiting forced union dues - thereby allowing workers covered by union contracts to enjoy union-negotiated benefits but to "free-ride" when it comes to the paying of dues. Most estimates have concluded that long-term union density is reduced by between 5 to 8 percent after the passage of a state right to work bill (See Moore, 1998). Section 14b unleashed a huge free-rider problem and undermined the incentive to join unions. Taft Hartley also undermined the power of many unions to exercise leverage in strikes. Unions were prohibited from engaging in secondary strike action, and this gradually undercut their ability to exert pressure on a firm's customer base, thereby enormously weakening their leverage. ${ }^{12}$ Unions were also made financially liable for damages resulting from illegal secondary actions and wildcat strikes. Lastly, on the organizing front, the Taft-Hartley removed the NLRB's discretion to

11 These causes of change in public attitudes are discussed in Palley (1998a, p.31 - 8).

12 In traditional labor disputes, unions were viewed as having potential power over both the supply of output and the demand for that output as other unionized workers displayed their solidarity for the cause. Subsequent to the secondary (or unified) strike restrictions of Taft-Hartley, unions were only left with the power to impact industrial supply to the extent that they could disrupt local production. The loss of the power of secondary action has become even more critical in today's globalized economy, which is characterized by multinational production and subcontracting. 
recognize unions on the basis of card check by prospective members. Instead, employers were given an automatic right to demand an NLRB recognition election, thereby opening the flood gates for the type of pre-election intimidation spending by business that is so visible today (Freeman and Kleiner, 1990: Friedman and Prosten, 1993).

Period IV: 1980 - present.

A final period can be identified from 1980 to the present. At the beginning of the 1980s the decline in union density began to accelerate, falling to $14.03 \%$ in 1995 . This acceleration suggests that the economy crossed a threshold, moving from the pull of a high-density equilibrium to that of a low-density equilibrium. The shift to more pro-business Republican government and the liberalization of international trade were two critical factors. These two developments are captured in Figure 7 which shows a relatively large downward shift of the union density schedule in the early 1980s. The event that is most emblematic of the environment facing unions during this time period was Ronald Reagan’s highly-publicized breaking of the Professional Air Traffic Controller's Organization (PATCO) strike and the rapid dismantling of the union. Reagan also changed the complexion of the National Labor Relations Board - the agency legally mandated to protect organizing rights - by appointing anti-labor members. The symbolism was heightened after Reagan’s 1984 reelection when the administration tried to hire non-union entertainers for the inauguration celebration (Goldfield, 1987).

Rapid globalization of production has been another salient feature of the economy during this period. The growth of international trade can be likened to the influx of immigrant workers during the late $19^{\text {th }}$ century, effectively placing domestic workers in direct competition with foreign workers. Many recent studies have identified a close relationship between greater international trade and the recalcitrant wage growth of US workers. Paul Krugman (1995) 
attributes 10 percent of the increase in U.S wage inequality in the 1970s and 1980s to trade, whereas Cline (1997) attributes 37 percent of the increase to trade. ${ }^{13}$ Yet, these two studies ignore the indirect effects on wages and wage inequality of trade-induced decreases in union density. Palley (1999) examines overall income inequality using the U.S. family income gini coefficient, and reports that 24 percent of the increase in inequality between 1980 and 1997 is directly attributable to increased openness, and this rises to $34 \%$ if the negative effect of trade on union density is taken into account.

Globalization can be thought of as exerting downward wage pressure in domestic labor markets. It does this by increasing the bargaining power of business relative to labor by giving business improved exit options. To the extent that globalization reduces the union wage premium, it will tend to reduce demand for unions and lower equilibrium density. The hemorrhaging of the heavily unionized manufacturing sector over the last five years, suggests that international wage competition has disproportionately impacted union workers. The phenomenon has prompted Joseph Stiglitz (1997) to observe that, "For all intents and purposes, unions no longer play a role in the wage negotiations of the sector that was once their bastion of strength.”14 Since 1995 union density has been roughly constant (between 12 to 14 percent), suggesting that it may have stabilized at a new low-density equilibrium.

\section{Looking to the future: strategic trade-offs}

The above model offers some interesting insights into the difficulties unions face rebuilding density. At this stage union density may be trapped in the low-density equilibrium. A successful rebound will require shifting the demand for density schedule up, but gains to density

13 Cited in Baker and Weisbrot (2001).

14 It is possible for globalization to exert equal downward pressure on both union and non-union wages, leaving the union wage premium and the demand for union density unchanged. In this event, globalization can be neutral with 
initially stand to be marginal. Re-creating the high-density equilibrium will involve a large upward shift of the demand function such that the high-density equilibrium becomes the global attractor. Given the influence of path-dependency on union density via attitudes, a robust rebound in union membership is unlikely without some exogenous change - such as labor law reform - that generates a large upward shift in union demand. However, the likelihood of substantial reform in the current political landscape is low. Labor law is in part a reflection of the general acceptance of unions, and changing it will require a popular movement in defense of collective bargaining.

Public attitudes toward unions thus represent a critical variable in determining the demand for unions, highlighting the importance of unions building broad political coalitions. However, this approach can also cause tensions, as illustrated by consideration of the minimum wage. Suppose public attitudes towards unions are a positive function of union support of the minimum wage and other programs benefiting the economically disadvantaged. Union support for such programs can be a double-edged sword as higher minimum wages have a positive impact on the market wage, which lowers the union wage premium and diminishes demand for unions. Palley (1998b) reports that the minimum wage positively impacts wages of the bottom $30 \%$ of female workers, and positively impacts wages of the bottom $20 \%$ of male workers. In this case, the demand for union density becomes $\left(10^{\prime}\right) \mathrm{D}=\mathrm{D}\left(\left[\mathrm{W}\left(\mathrm{U}_{\mathrm{t}-1}, \ldots\right)-\mathrm{DUES}\right] / \mathrm{V}\left(\mathrm{U}_{\mathrm{t}-1}, \mathrm{~W}_{\mathrm{MIN}}, \ldots\right), \mathrm{g}\left(\mathrm{U}_{\mathrm{t}-1}, \mathrm{DUES}, \mathrm{LAW}\right)\right.$,

$$
h\left(W\left(U_{t-1}, \ldots\right) / V\left(U_{t-1}, W_{M I N}, L A W\right), \operatorname{ATT}\left(W_{M I N}, \ldots\right)\right)
$$

Raising the minimum wage (like most worker solidarity legislation) then has an ambiguous impact on demand for union representation. It improves public attitudes towards unions, which 
raises demand for union representation; and it also lowers business opposition spending by lowering the union wage premium. Balanced against this, minimum wage hikes raise the market wage and lower the union wage premium, which directly reduces demand for union representation. If the latter impact dominates, a higher minimum wage could reduce demand for unions by reducing the wage gain from joining unions.

The possibility that minimum wage increases can undermine demand for union density raises an even deeper political conundrum. Trade unions, today and historically, have been a major political force pushing for social welfare legislation that ameliorates the callousness and inequities of market-based economies. Yet, to the extent that they succeed and the legislation is effective, they risk undermining the demand for union density. It bears mention that the achievement of a higher minimum wage is a one-time adjustment with no permanent process put in place to protect the purchasing power and bargaining position of the workers. Unionization, however, is an on-going evolutionary relationship - the primary purpose being the provision of a countervailing force against the employer's wage-setting power.

Another trade-off concerns the setting of membership dues. Higher union dues provide the resources needed to finance effective organizing, and this raises demand. At the same time, they lower the union wage premium, which reduces demand. This dilemma is particularly problematic when it comes to organizing low-wage labor markets where industry conditions may leave relatively less space for unions to force up the union wage. If industry conditions compel dues to be low, this may make it cost-ineffective to organize and administer unions in particular industries beyond a certain level of union density.

Such reasoning suggests that union density in advanced capitalist societies may be subject to long wave cycles that are driven by changing socioeconomic conditions. The process 
might work as follows. Periods of union weakness contribute to business leaders seeking to restore the opportunism of the market by repealing ameliorative social welfare legislation. This creates conditions of widespread hardship that in turn contribute to a social backlash that fuels public support for unions. The shift in public attitudes then begins the process of shifting the economy back toward the high-density equilibrium. In tandem with this shift, there begins a new cycle of union sponsored progressive social welfare legislation that diminishes both direct demand for and public support of unions by reducing economic inequities and hardship. Support for unions may also begin to wane to the extent that they are successful in solving wage and income distribution problems, and the public comes to deem unions as "no longer necessary." At this stage, eroding public support triggers a long decline back to the low-density equilibrium.

The model highlights the significance of the union wage premium in determining demand for density. New members want unions to deliver economic benefits. In this regard unions face a further difficulty in that the union wage premium has been steadily falling since the early 1980s. A recent Bureau of Labor Statistics report shows that from 1984 to 1990 non-union worker wages and salaries rose faster than those of union workers (Foster, 2000). Union workers recovered the edge from 1992 - 94, since then, however, non-union wages and salaries have again been rising faster.

Qualifying this is the fact that the impact of the union wage premium may work in more complicated ways. Thus, public attitudes may be negatively impacted by too large a wage premium, perhaps reflecting a belief that union workers are being unfairly over-paid. In this case, a falling union wage premium could translate into greater public support that actually increases demand for density. Beyond this, there is the more fundamental point that the premium is a ratio of wage levels. It can be viewed either as the union wage being too high or the market 
wage being too low. If the public comes to see the issue as an inadequate market wage, this would blunt charges that a high union premium reflects over-payment and would build support for both higher union wages and higher market wages.

The ratio of the gross union wage to the market wage is an especially important variable influencing business opposition spending. This has salient public policy consequences in the U.S. where health and pension benefits are bargained for. These bargained benefits push up the cost of union workers and give firms a stronger incentive to oppose unions. Mishel, Bernstein and Schmitt (1999) report that in 1997 the union compensation premium in the U.S. was $\$ 6.20$ or $35.9 \%$, and $\$ 2.05$ of this was attributable to superior insurance and pension benefits. This contrasts with European social democracies where benefits are provided by the state, which may explain why European business is more accepting of unions. This suggests that if employer opposition is the principal obstacle to union density then an important union political priority should be to change the current system from one of bargained health benefits to one of state provided benefits.

\section{Conclusion: a new agenda for research on unions}

This paper has developed a new economic model of union density. The model departs from the existing theoretical literature by focusing on the demand for union density and introducing the influence of public attitudes towards unions, union involvement in labor and social legislation and the path-dependent effects associated with varying union density. In doing so, it extends the scope of analysis beyond a narrow union - firm focus. Unions are institutions that exist within society, and their ability to thrive depends heavily on labor law and public support. This implicitly brings the analysis of unions into the fold of "law and economics." Laws governing employer rights of dismissal, employee rights to form unions, and employee rights to 
obtain redress in the event of unfair dismissal are critical. Legal and administrative rules and restrictions matter enormously, and this is clearly illustrated by comparison of discharge rates for organizing in industries governed by the National Labor Relations Act versus the Railway Labor Act (Morris, 1998).

For economists, the suggested approach to understanding union density opens a new economic research agenda that explores how different rules and remedies might impact union density, what determines the effectiveness of union organizing strategies, and what determines the extent and effectiveness of employer opposition to unions. It also suggests research into what type of representation people want at work, and what types of institution have the best prospects of delivering those demands. This is important as it can show how unions need to develop and evolve in response to changing employment relations and worker attitudes. Finally, the suggested approach links the economics of unions with broader sociological studies of unions in which union density is placed within an institutional context. In his comparative cross-national study of union density, for example, Western (1997) identifies three crucial institutional conditions: strong working class political parties, centralized collective bargaining, and unionrun unemployment insurance. Our model has shown that many of these institutional conditions can be analyzed in terms of their impact on the supply and demand for union services, helping understand union density in particular countries - even one as idiosyncratic as the United States. 
Figure 2. The Determination of Equilibrium Union Density in the Freeman (1998) Model.

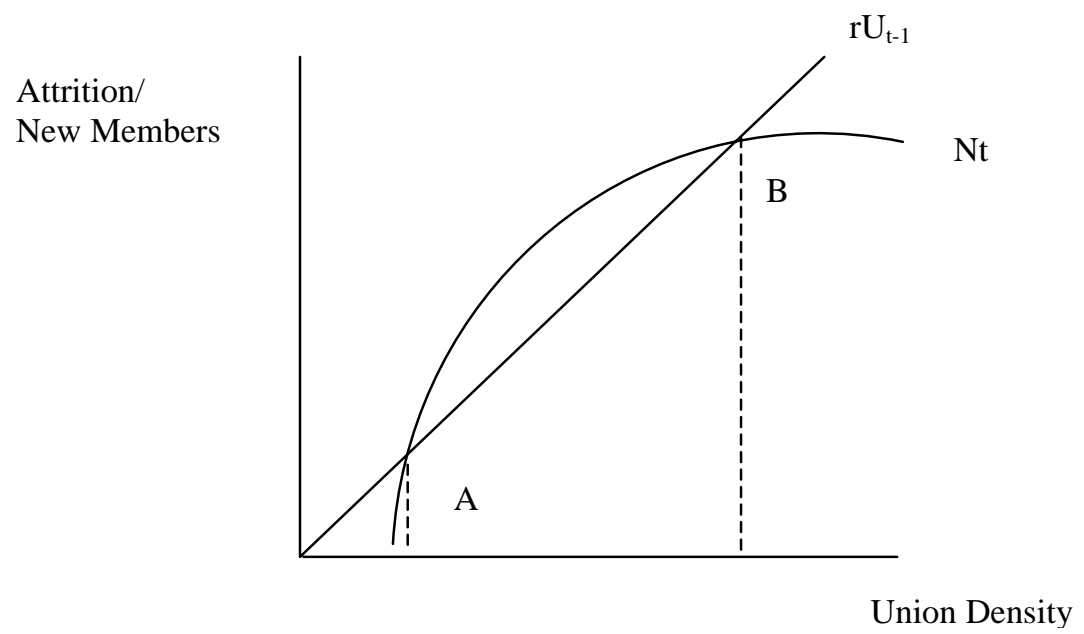

Figure 3. The Wage Premium as a Function of Union Density

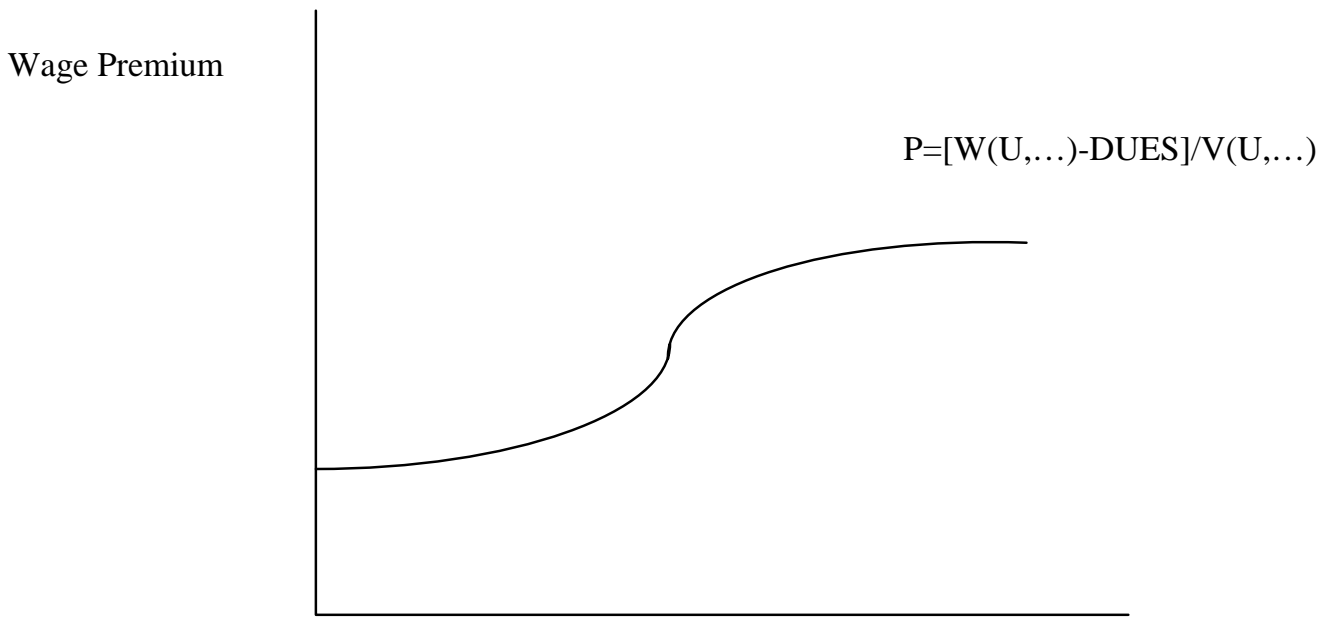

Union Density 
Figure 4. Determination of Equilibrium Union Density

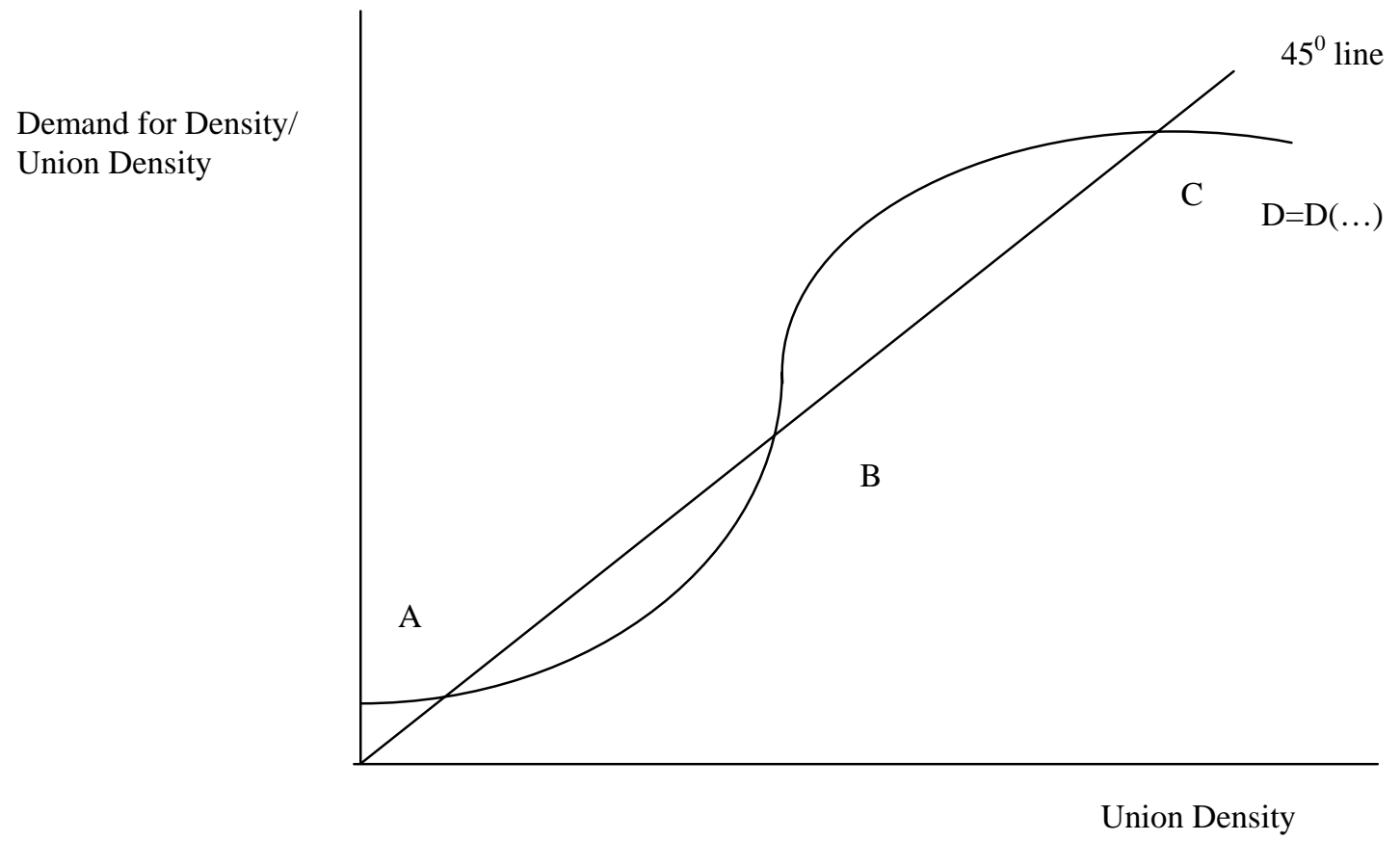

Figure 5. The Shift to a High-Union Density Equilibrium between the 1930s and 1940s.

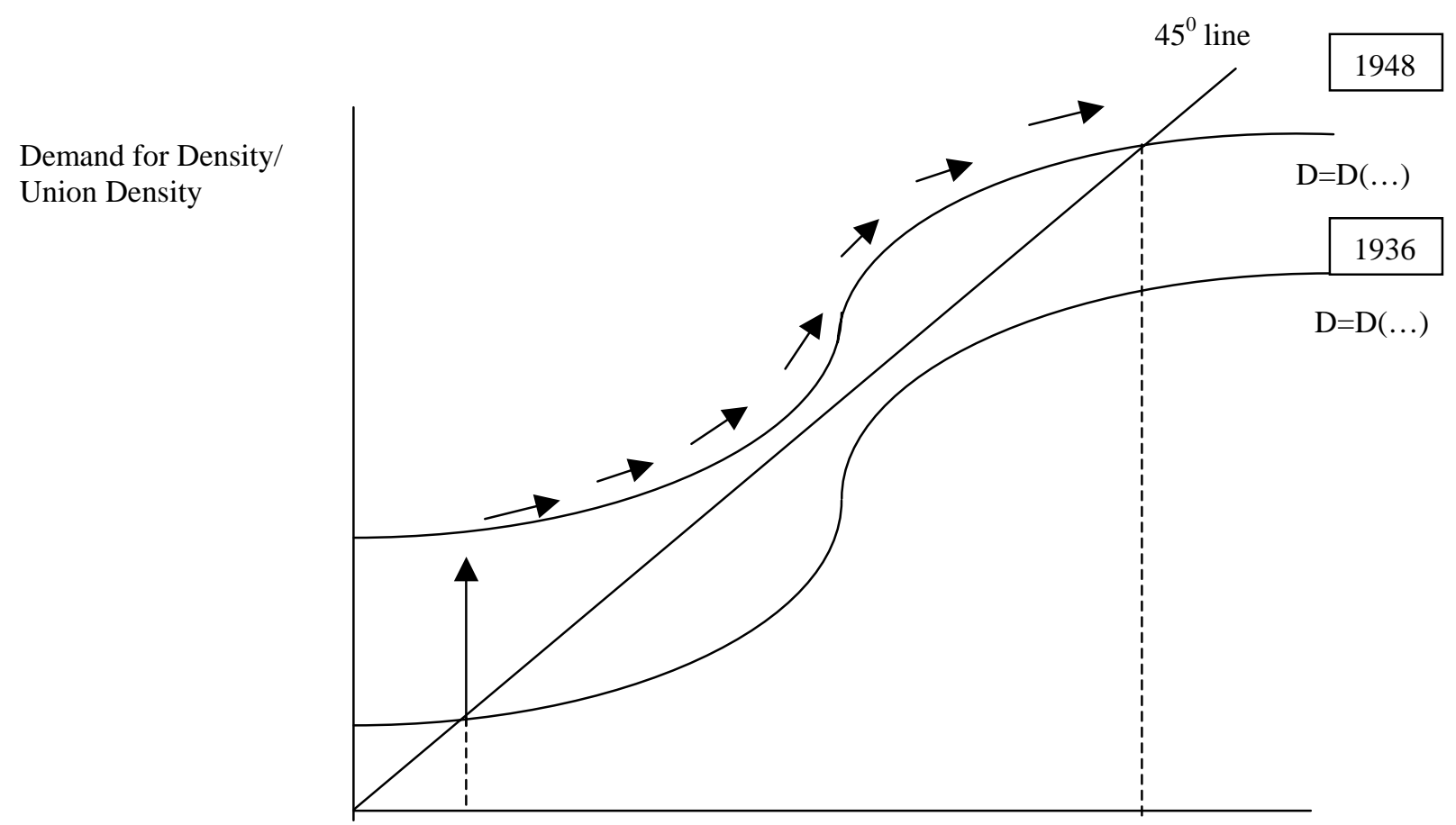


Figure 7. Declining Union Density since the 1960s.

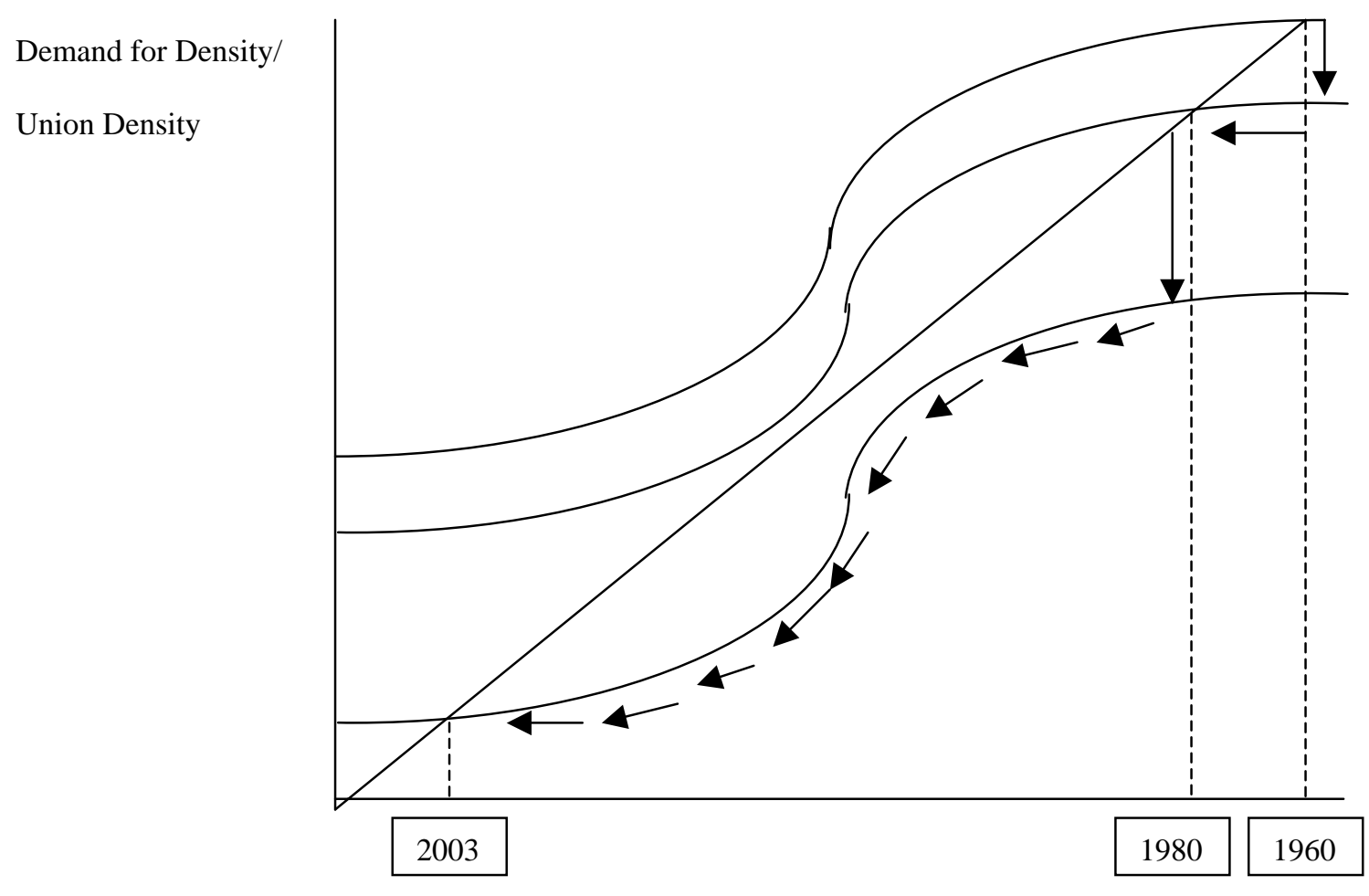

Union Density 
Figure 1. Union Density in the US, 1880-2002

-Total Union Density -

Source: 1880-1948- Freeman, 1997; 1948-2003 Bureau of Labor Statistics

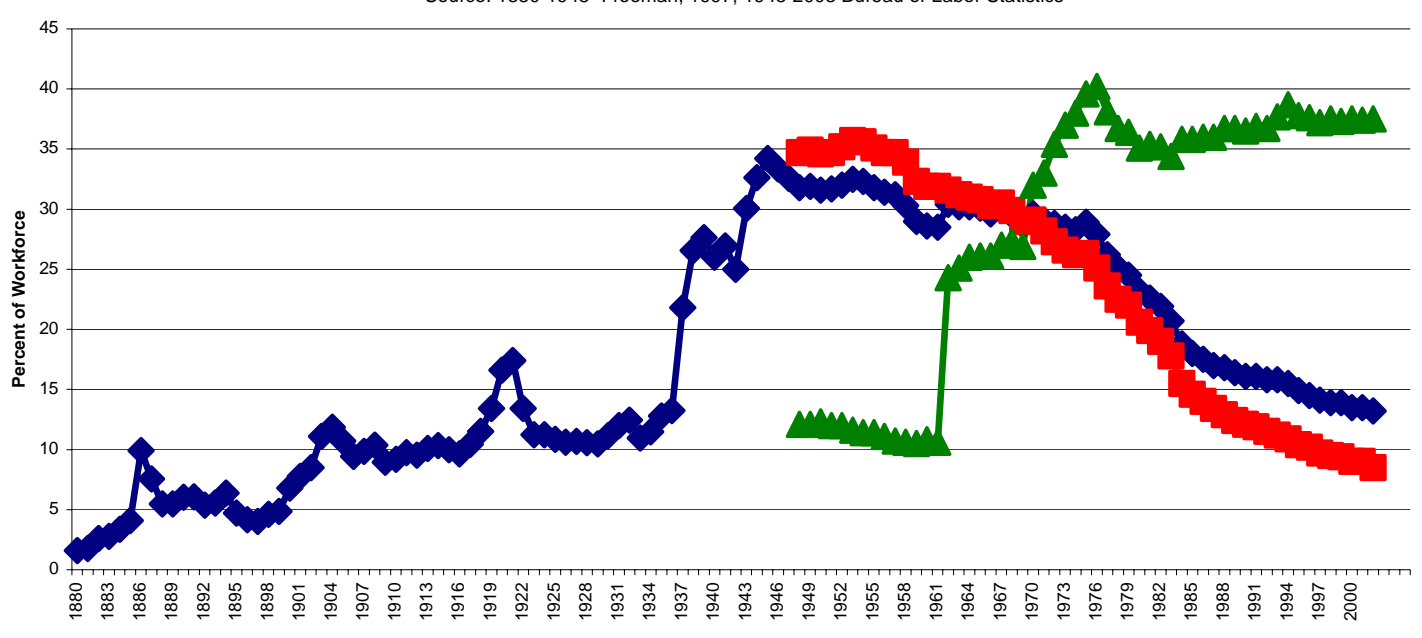



Figure 6. Public Support for Unions and Election Win Rates

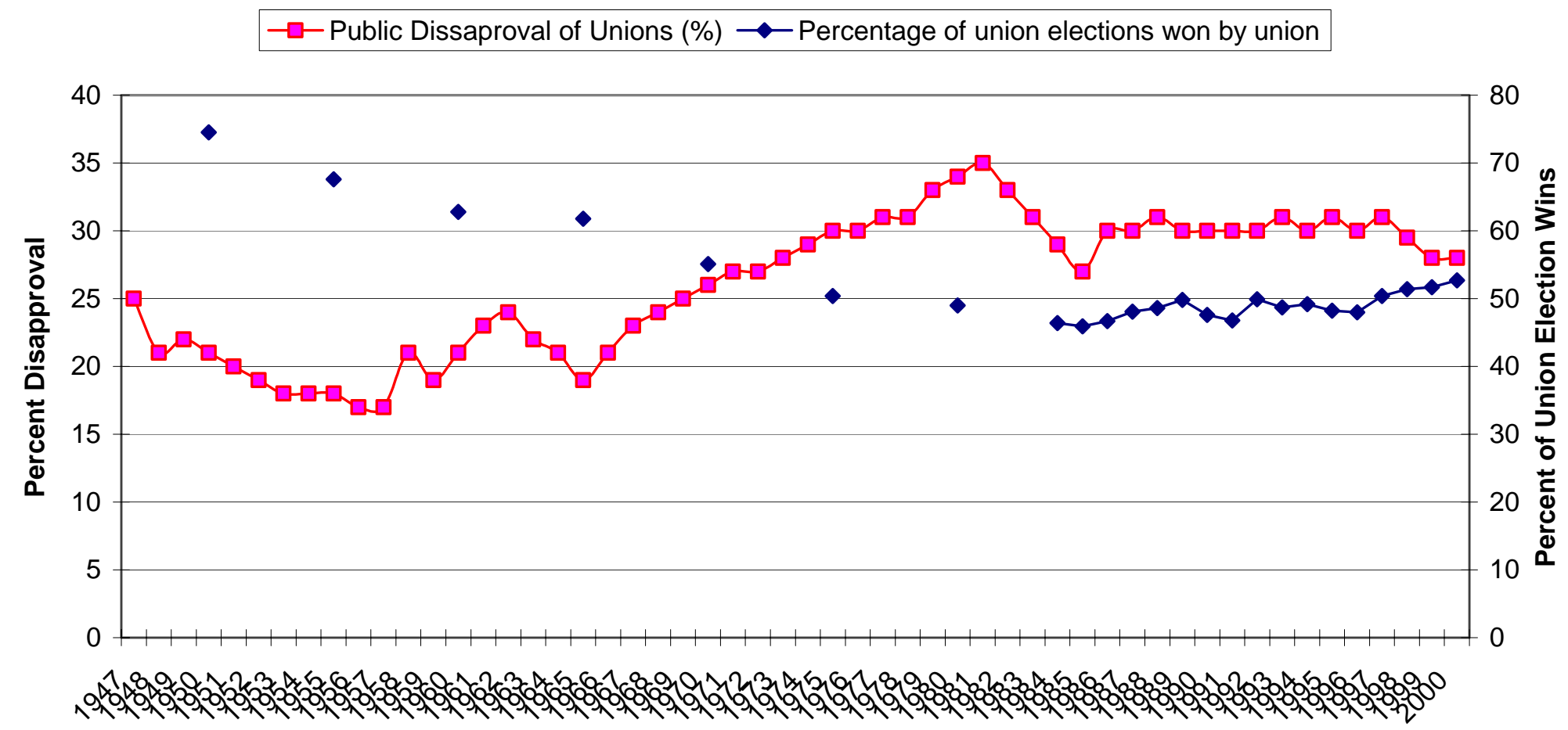




\section{References}

Blanchflower, D.G., and Oswald, A.J., The Wage Curve, Cambridge, M.A.: MIT Press, 1994.

Beard, Charles and Mary. The Rise of American Capitalism. New York, NY: MacMillan, 1933.

Chandler, Alfred. The Visible Hand: The Managerial Revolution in American Business

Cambridge MA.: Belknap Press. 1977.

Cline, W., Trade and Income Distribution, Institute for International Economics, Washington, DC, 1997.

Foster, A.C., "Union-nonunion Wage Differences, 1997,” Compensation and Working Conditions, 5 (Spring 200), 43 - 6.

Freeman, R.B., "Spurts in Union Growth: Defining Moments and Social Processes," in Bordo, Goldin, \& White (eds.), The Defining Moment: The Great Depression and the American Economy in the Twentieth Century, Chicago: The University of Chicago Press, 1998.

, and Kleiner, M., Employer Behavior in the Face of Union Organizing Drives,” Industrial and Labor Relations Review, 43 (April 1990), 351 - 65.

Friedman, S., and Prosten, R., "How Come One Team Still Has to Play with its Shoelaces Tied Together?” Proceedings of the 1993 Spring Meeting of the Industrial Relations Research Association, 1993, 477 - 85.

Goldfield, Michael. The Decline of Organized Labor in the United States. Chicago and London: University of Chicago Press, 1987.

Heilbroner Robert and Aaron Singer. The Economic Transformation of America: 1600 to Present. New York, NY: Harcourt Brace College Publishers. 1999.

Hogler, Raymond, Steve Shulman and Stephan Weiler. Do right-to-work laws matter?:explaining the variation in union density among states. Fort Collins, CO. Center for Research on the Colorado Economy, 2003.

Krugman, P., “Growing World Trade: Causes and Consequences,” Brookings Papers on Economic Activity, 1995.

McDonald, I.M., and Solow, R.M., "Wage Bargaining and Employment,” American Economic Review, LXXI (December 1981), 896 - 908.

Quarterly Journal of Economics, C (November 1985), 1115 - 41. 
Mishel, L., Bernstein, J., and Schmitt, J., The State of Working America, 1998 - 99, Cornell University Press: Ithaca, 1999.

Moore, William J. “The Determinants and Effects of Right-to-Work Laws: A Review of the Literature.” Journal of Labor Research, 1998. 445 p. 19.

Morris, C.J., “A Tale of Two Statutes: Discrimination for Union Activity Under the NLRA and RLA,” Employee Rights and Employment Policy Journal, 2 (1998), 317 - 60.

Palley, T.I., “The Effect of Unemployment Among Union Members on Union Wage Contracts," Atlantic Economic Journal, XVI (September 1988), 19 - 30.

-------------, Plenty of Nothing: The Downsizing of the American Dream and the Case for Structural Keynesianism, Princeton: Princeton University Press, 1998a.

------------, “The Minimum Wage and the Low Wage Labor Market: A Wage Curve Analysis,” AFL-CIO Public Policy Department, Technical Working Paper, T011, 1998b.

--------------, “Accounting for Income Inequality in the U.S.: The Role of Unions, the Minimum Wage, Unemployment, Family Structure, and International Trade,” AFL-CIO Public Policy Department, Economic Policy Paper, E031, AFL-CIO, 1999.

Skillman, G.L., "Efficiency vs. Control: A Strategic Bargaining Analysis of Capitalist Production,” Review of Radical Political Economics, 23 (1991), 12 - 21.

and Ryder, H.E., "Wage Bargaining and the Choice of Production Technique in Capitalist Firms,” in Bowles, Gintis, and Gustafsson (eds.), Markets and Democracy: Participation, Accountability, and Efficiency, Cambridge: Cambridge University Press, 1993.

Shaked, A., and Sutton, J., "Involuntary Unemployment as a Perfect Equilibrium Bargaining Model,” Econometrica, 52 (1984), 1351 - 1364.

Stiglitz, Joseph. Microeconomics Second Edition. New York, NY: WW Norton, 1997.

Tausig, F. The opposition of interest between employer and employee: Difficulties and remedies. In Wertheim Lecture on Industrial Relations. Cambridge, MA: Harvard University Press, 1929.

Western, B., Between Class and Market: Postwar Unionization in the Capitalist Democracies, Princeton: Princeton University Press, 1997. 